\title{
The influence of relational capital and networking on the internationalization of the university spin-off
}

\author{
María del Carmen Peces Prieto(D), María Amalia Trillo Holgado (iD \\ Universidad de Córdoba (Spain) \\ z12peprm@uco.es,maru.trillo@uco.es
}

Received October, 2017

Accepted January, 2019

\section{Abstract}

Purpose: This paper analyzes the influence of relational capital in business internationalization, focusing on university spin-offs.

Design/methodology: A literature review based on the theories of relational capital and networking from an international perspective. A theoretic model is then developed.

Findings: The analyses in this paper show that relational capital influences the internationalization of university spin-offs in a positive manner. In addition, the firm's performance in its international activities depends on its capabilities to create and maintain relationships with the relational capital agents.

Research limitations/implications: This is a theoretical paper; because of this, it would be advisable to complete it using a hybrid methodology, i.e., qualitative and quantitative analyses. Moreover, it would be useful to consider other sectors besides the technology sector.

Practical implications: Following the literature review, which is limited to studies that jointly address these issues, a strategic analysis tool is developed that aims to improve the management of the relational capital to create value. This is carried out as part of the decision-making process related to the effect and links among the elements of the aforementioned capital, taking into account an international perspective.

Social implications: In the current globalized economy, intangible management is more important than it used to be, in order to obtain competitive advantages in the business world. Furthermore, internationalization becomes an escape route in the face of a difficult economic situation, in which small companies must overcome significant problems in the local market.

Originality/value: Nowadays, business internationalization is very important, and in this context, relational capital management plays a critical role in achieving competitive advantages. In spite of this, the literature review is restricted to studies that jointly address both issues (relational capital and internationalization). This makes for an interesting challenge, which is what this paper attempts to examine, through application in one of the most influential sectors in economic development.

Keywords: Relational capital, Networking, Internationalization, University spin-off

Jel Codes: M16, O34 


\section{To cite this article:}

Peces Prieto, M.C., \& Trillo Holgado, M.A. (2019). The influence of relational capital and networking on the internationalization of the university spin-off. Intangible Capital, 15(1), 22-37.

https://doi.org/10.3926/ic.1186

\section{Introduction}

The objective of the present research is to analyze the influence of relational capital and networking on the internationalization of university spin-offs. To this end, a thorough review of the available literature has been carried out, based on the impact and relevance of the main scientific journals in the field of applied and social sciences (JCR, H Indexes, etc.) starting in the 1990s until now, with an occasional previous citation as necessary.

The study of the measurement and management of intellectual capital is relatively recent. In recent decades, the subject of analysis has been private companies, but there is currently growing interest in its application to universities and research centers (Owais, 2014). This hereby gives broad recognition to the crucial role the university plays in the current context of globalization, contributing to economic growth, the creation of sustainable employment and competitiveness in international markets (Audretsch, 2013).

Intellectual capital is defined as a set of strategic resources based on knowledge that enable an organization to create sustainable value. It encompasses three types of capital: human, structural and relational. Numerous authors recognize that the economic wealth of organizations comes from the aforementioned assets and their proper management (Ozdemir, 2017), offering a potential competitive advantage from which economic growth must emerge (De Leaniz \& Del Bosque, 2013), and that constitutes a source of long-term sustainable benefits (Sydler, Haefliger \& Pruksa, 2014).

Nowadays, the survival of many companies is linked to their internationalization, which makes the management of intangible assets even more necessary. Given the importance that establishing relationships with other agents in the environment has for companies in order to obtain information and incorporate new knowledge, this study is presented as preliminary, opportune research focused on one of the basic elements of intellectual capital, which is relational capital. It is closely associated with the phenomenon of business internationalization, since most companies are integrated within a network of relationships with other organizations, entities and society in general, as well as with other market agents. Stressed is the notion that performance in international business will depend to a large extent on their ability to build and maintain said network (Federico, Kantis, Rialp \& Rialp, 2009). Relational capital is thus presented as a key element in business internationalization, since the different relationships to which this type of capital refers give companies a greater chance of success in internationalization, which in turn results in greater financial profits (Presutti, Boari \& Fratocchi, 2016).

Specifically, relational capital refers to the value of the company's relationships with the individuals and organizations with whom it performs its activity (Hormiga, Batista-Canino \& Sánchez-Medina, 2011), including relationships with external interest groups, suppliers, dealers, partners, clients and other influence groups (CIC, 2011; Vatamanescu, Zbuchea, Pînzaru \& Andrei, 2016); this also includes the company's image and reputation.

The leveraging framework of the relational capital is therefore analyzed in business internationalization, focusing on the study of university spin-offs, since in recent years they have become one of the most effective mechanisms to transfer research and technology results to the production sector, playing a crucial role in the processes of innovation and socioeconomic growth (Iglesias et al., 2012, 2014).

The bibliographical evidence shows the existence of areas of opportunity to conduct empirical research that analyzes the joint relationship between relational capital and technology, as well as its applications in emerging sectors, such as high-tech companies (Rodenes \& González, 2008), and its expansion into the international realm (Iglesias et al., 2012, 2014). In spite of the existence of research on each of the elements that concern us here (relational capital, networking, internationalization and spin-offs), their joint analysis is scarce, which explains the 
existence of the aforementioned areas of opportunity to develop a study that covers each and every one of the elements on which the present research is based.

The present article begins with the conceptualizaction, characterization and overall review of the literature related to the companies being studied, followed by the specific analysis of the most relevant theories of relational capital and networking in an international context, from the perspective of their complementarity. Later, based on the review of the available research, some hypotheses are proposed for special consideration and analysis, ending with the development of a model that intends to facilitate strategic decision-making for companies with regard to their relational capital as a key factor in their internationalization process.

\section{University spin-offs: The concept, characterization and related studies}

Spin-offs are technology based firms (TBFs) that emerge in the area of universities or technology centers. Their main objective is to transform scientific knowledge and research results into marketable products or services (Zahra, Van de Velde \& Larraneta, 2007), facing uncertainty of both the market and in relation to the scientifictechnological research they conduct (Visintin \& Pittino, 2014).

There is a great deal of ambiguity surrounding the term university spin-off, which makes it difficult to find a single definition that makes it possible to conduct a rigorous study of this phenomenon (Iglesias et al., 2012, 2014). In the United States, these are referred to as start-ups, stressing the organization's greater capacity for growth as a result of its technological and innovative character; in Great Britain, they use the term spin-out, emphasizing the independence of the company that is created (Vargas, 2011), while in the rest of Europe, the term spin-offs is usually dominant.

This work considers university spin-offs to be those companies created based on knowledge or technology developed under the auspices of a university or public or private research centers by the staff members associated with them, and which engage in the commercial exploitation of said knowledge or technology (Rodeiro, 2008; Valmaseda \& Hernández, 2012; Treibich et al., 2013; Iglesias et al., 2012, 2014).

This business phenomenon has certain particularities, among which the most important ones are (Lockett \& Wright, 2005; Rodeiro, 2008; Valmaseda \& Hernández, 2012; Beldad, 2013; Treibich et al., 2013; Iglesias et al., 2012, 2014):

- The university origin of the founder.

- Development of technology or knowledge generated at the university or public or private research centers, as well as its direct transfer to the company.

- Commercial exploitation of the results of the technology or knowledge originating at the university.

- Licensing of the intellectual property rights of the university or public or private research centers.

- Contribution to the economy and social welfare.

- Differential advantage based on high-tech and intensive use of knowledge.

- Small size and number of employees (technologists and/or doctors).

- Participation in external networks and support systems.

- $\quad$ Limited maturity.

- Difficulty with financing (they require large investments and longer periods to capitalize on them).

- Internationalization (due to the great innovation of their products).

The review of the literature reveals many different focuses from which the spin-off phenomenon has been considered. These are summarized in Table 1. Many authors have attempted to conceptualize, characterize and 
taxonomically classify these companies, and to analyze the factors that have the greatest influence on their creation and success. Likewise, the role was studied that networking plays, firstly, examining the formation of networks of relationships, and then those established by the founder of the company. Very few studies examine the relational capital of these companies and fewer yet consider their influence on their internationalization. More recently, research has been conducted on the intellectual capital of universities and the knowledge transfer facet of spin-offs to the market.

\begin{tabular}{|l|l|}
\hline Topics considered & Authors \\
\hline Conceptualization & $\begin{array}{l}\text { McQueen \& Wallmark, 1982; Carayannis, Rogers, } \\
\text { Kurihara \& Allbritton, 1998; Shane, 2004; Rodeiro, 2008; } \\
\text { Valmaseda \& Hernández, 2012; Beldad, 2013; Treibich, } \\
\text { Konrad \& Truffer, 2013; Iglesias, Maldonado \& Velasco, } \\
\text { 2014 }\end{array}$ \\
\hline Characterization and taxonomic analysis & $\begin{array}{l}\text { Vargas, 2011; Iglesias, Maldonado \& Velasco, 2012, 2014; } \\
\text { Valente, 2014; Visintin \& Pittino, 2014 }\end{array}$ \\
\hline Factors of creation and success & $\begin{array}{l}\text { Barroso-González, Jiménez-García, M. \& Pérez- } \\
\text { González, 2014 }\end{array}$ \\
\hline Integration in networks of relationships & $\begin{array}{l}\text { Pérez \& Sánchez, 2003; Walter, Auer \& Ritter, 2006; } \\
\text { McFadyen, Semadeni \& Canella, 2009; Steinar, 2014 }\end{array}$ \\
\hline $\begin{array}{l}\text { Role of the founder and his/her previously } \\
\text { established relationships }\end{array}$ & $\begin{array}{l}\text { Landry, Amara \& Rherrad, 2006; Ozgen \& Baron, 2007; } \\
\text { Huang, Lai \& Lo, 2012; Villanueva-Felez, Fernández- } \\
\text { Zubieta \& Palomares-Montero, 2014; Steinar, 2014 }\end{array}$ \\
\hline $\begin{array}{l}\text { Analysis of relational capital or some of its elements } \\
\text { Stuart, 2000; Chang, 2003; Díaz-Díaz \& De Saá-Pérez, } \\
\text { 2007; Alarcón, 2013; Steinar, 2014 }\end{array}$ \\
\hline $\begin{array}{l}\text { Analysis of intellectual capital in universities } \\
\text { Role of the university as a generator of knowledge } \\
\text { (with the spin-off responsible for transferring it to } \\
\text { the market) and its contribution to economic growth }\end{array}$ & \begin{tabular}{l} 
Owais, 2014; Villasalero, 2014 \\
\hline
\end{tabular} \\
\hline
\end{tabular}

Table 1. Topics considered in the study of spin-offs

\section{The relational capital and networking of spin-offs from an international perspective}

In spite of the fact that relational capital has become a means to obtain competitive advantages in a dynamic and global environment, it has not been studied in any consistent manner. Through the models for measuring and managing intellectual capital presented in the literature, reference is observed to have been made to relational capital from different perspectives and different conceptualizations. There is no one generally accepted definition, and relational capital has not even been included in all the existing models, in spite of the fact that the Theory of Knowledge in which this construct is framed presents it as the main source of sustainable competitive advantage for organizations.

In Kaplan and Norton's Balanced Business Scorecard (1992), relational capital appears reflected in the "perspective of clients", which is used to analyze how to create value for the client, how to meet their demand and why the client is paying for it. Following these lines, Edvinsson (1997) refers to the "customer focus" as part of the "Skandia Navigator" model, and Saint-Onge (1996) once again refers to customer capital in his Canadian Imperial Bank model. More recently, Chen (2008) is another author who refers to relational capital through the so-called customer capital, highlighting his interest in customer loyalty to the organization and trust in relationships.

In other works, the authors expanded the concept of relational capital, also including relationships with suppliers, the competition, partners, allies, and public entities and institutions, in addition to relationships with customers. This is the case of Roos and Roos (1997), who extend the study of relationships between organizations and their customers, referring to this category of intellectual capital as customer and relationships capital. In it, they also include suppliers, partners and investors. 
Camisón, Palacios and Devece (2000), in their Nova Model, refer to the relationships the company has with agents in its environment (customers, suppliers, the competition, allies, public administrations, the environment, consumer associations, etc.) through what they call social capital.

Along the previous lines, there are other authors such as Bontis (2001), who in his so-called customer capital, considers the relationships that the company has with its competitors, suppliers, associations and the government. Meanwhile, Flostrand (2006) proposes a classification based on three basic dimensions: relationships with customers, relationships with suppliers and alliances.

Other authors, such as Brooking (1996) and Sveiby (1997), extend relational capital beyond relationships with customers and other agents, adding an additional element, namely, reputation and corporate image. Brooking (1996) defines the so-called "market assets," referring to those that are derived from a beneficial relationship between the company and its market and the company with its customers. These include product brands, repeat business, distribution channels, corporate name and image, among other aspects that give the company a competitive advantage. Sveiby (1997), in turn, in his so-called "external structure," includes relationships with customers and suppliers, as well as commercial brands and the corporate reputation or image. More recently, Gogan and Draguici (2013) refer to relational capital through the so-called customer capital, which refers to the connections and relationships the organization has with actors in the external environment, i.e., relationships with customers and other agents. In this capital, these authors include relationships with customers, and suppliers, as well as the corporate image (Fletcher, 2008; Guercini \& Runfola, 2010).

Finally, the Intellectus Model is one of the most complete, given the detail with which it conducts the study of the intellectual capital, highlighting five types of capital instead of the traditional three (human, organizational and relational); it establishes two components of relational capital, which are business capital and social capital. With them, the model refers to the relationships between the business and its customers, suppliers, shareholders, institutions and investors, allies, competitors, institutions for the promotion and improvement of quality, Public Administrations, the media and institutions associated with corporate image, relationships in connection with environmental protection, social relationships and corporate reputation. It defines relational capital as: "A set of knowledge that is incorporated in the organization and people as the result of the value derived from the relationships it maintains with market agents and society in general" (CIC, 2003, 2011).

In the academic environment, this capital includes all the activities and relationships between the university and the non-academic partners (companies, non-profit organizations, Public Administrations and society in general) (Owais, 2014).

Among the reasons why a company might decide to network with other organizations and agents are access to new markets, the search for opportunities and efficiency. Belonging to networks is one of the bases that support the creation of relational capital.

Authors like Fonfría (2010) state that technological activities have a strong influence on the capacity for internationalization of countries, sectors and companies. This thus stresses the importance of TBFs, and in particular, of university spin-offs, as an element that favors the international economy (Iglesias et al., 2014).

It is important to point out the effect on the business activity that the elements of relational capital have and the links that are developed among them. Stuart (2000) analyzes, in this sense, the relationships with allies, stating that those with technological capacity have a positive influence on the rate of innovation in the organization. Chang (2003) also comments along these lines, but he considers customers, suppliers, competitors, universities and research institutions. Díaz-Díaz and De Saá-Pérez (2007) also stress the relationships with customers and suppliers to the extent that they provide useful information. In spite of the fact that the aforementioned authors have actually studied relational capital or some of its elements in relation to spin-offs, they have focused on determining their influence on the results of the innovation, without any special mention of the international framework. In this regard, a very few authors have been identified that have engaged in the study of the relational capital of university spin-offs in an international context, as explained below. Alarcón (2013) claims that this capital in fact represents a source of competitive advantages for the spin-offs, highlighting the 
development of strategic alliances. Steinar (2014), in turn, unlike Alarcón (2013), delves deeply into the analysis of different relationships with relational capital agents, i.e., customers, suppliers, competitors, distributors and the government, focusing on the study of the role that the founding team plays in the construction of international networks.

The literature analyzing the networking of spin-offs is more extensive. These companies favor setting up networks of collaborations with other companies and countries, appear more open to collaboration and establishing alliances and promote taking advantage of synergies, with important benefits for those involved. In this way, collaborations and the nature of the networks to which the researchers belong give both the individual and the organization a certain competitive advantage that is fundamental for generating and disseminating scientific knowledge (Villanueva-Felez et al., 2014).

With regard to this research, it is important to point out the analysis of the networks of relationships to which the organizations belong, since these complement the study of the influence of relational capital and its different elements in the internationalization of university spin-offs. Table 2 shows the main research on relational capital and networking related to this type of companies.

\begin{tabular}{|l|l|}
\hline What has been studied & Authors \\
\hline Importance of relations with allies on the rate of innovation & Stuart, 2000 \\
\hline $\begin{array}{l}\text { Relevance of the effect of the elements of relational capital } \\
\text { (customers, suppliers, competitors, universities, research institutions) } \\
\text { on the innovation process }\end{array}$ & Chang, 2003 \\
\hline $\begin{array}{l}\text { Importance of relations with customers and suppliers in the } \\
\text { innovation process }\end{array}$ & Díaz-Díaz \& De Saá-Pérez, 2007 \\
\hline $\begin{array}{l}\text { Relational capital as a source of competitive advantage for TBFs, } \\
\text { and in particular, for spin-offs, focusing on strategic alliances }\end{array}$ & Alarcón, 2013 \\
\hline $\begin{array}{l}\text { Analysis of the international networks of academic spin-offs, } \\
\text { focusing on the founding team, alluding to different relational capital } \\
\text { agents (customers, suppliers, competitors, distributors and the } \\
\text { government), but delving deeper into the development of networks } \\
\text { as opposed to the company-agent relationships themselves }\end{array}$ & Steinar, 2014 \\
\hline $\begin{array}{l}\text { Management of knowledge and intellectual capital in universities and } \\
\text { research centers }\end{array}$ & Owais, 2014 \\
\hline
\end{tabular}

Table 2. Study of relational capital and networks in spin-offs

The analysis of the available literature reveals a lack of studies related to the analysis of the influence of relational capital and the elements that it consists of in the internationalization process of university spin-offs. This article intends to fill the void in the literature with regard to the full analysis framework focused on how each of the relationships is begun, developed and consolidated that the company establishes with the different agents in its environment (elements of relational capital), detailed from the perspective of networks, through the study of different aspects, such as the degree of commitment acquired, the links established, the type of implementation, etc., all within an international context. The ultimate goal is to strategically observe the framework of influence that each element of the relational capital exerts in the internationalization process of the university spin-offs.

\section{Suggestion of hypotheses}

Internationalization is key in current times, to the point that some spin-offs are internationalized practically from the time they are created; these are said to have been born global. Due to the technology that they develop, they need a broader market than the national market in order to market their products/services. In other words, the internationalization of spin-offs can be observed from a very early phase, even in their origin, or through a gradual process. 
In the technology sector, establishing a network of relationships with other companies, social or economic institutions or with society in general makes the internationalization process much faster (Hollensen, 2014).

In short, through relational capital, organizations can strengthen their internationalization process, maintain both internal and external relationships, generate competitive advantages, expand their resource base (both financial and non-financial) and facilitate access to information, thus reducing the probabilities of failure through knowledge about the environment and potential competitors.

Thus, one of the hypotheses supporting this work is:

\section{H1: There is a positive relationship between relational capital and the internationalization of university spin-offs.}

It is important, in turn, to analyze the influence of each of the elements that make up this capital individually, in order to draw more profound conclusions that enable us to identify those with the greatest influence, forming a systematic focus, on the success of the internationalization of these companies.

The elements that form part of this research emerge from the review of the literature, as they are the ones most commonly used by the different authors (Table 3).

\begin{tabular}{|l|}
\hline CUSTOMERS \\
Edvinsson, 1997; Kaplan \& Norton, 1992; Brooking, 1996; Bontis, 1996; Sveiby, 1997; Roos, Roos, Dragonetti \\
\& Edvinsson., 1997; Euroforum, 1998; Camisón et al., 2000; Flostrand, 2006; Chen, 2008; CIC, 2011; Gogan \\
\& Dreguici, 2013; Presutti et al., 2016 \\
\hline SUPPLIERS \\
Kaplan \& Norton, 1992; Bontis, 1996; Sveiby, 1997; Roos et al., 1997; Euroforum, 1998; Camisón et al., 2000; \\
Flostrand, 2006; CIC, 2011; Gogan \& Dreguici, 2013 \\
\hline COMPETITION \\
Bontis, 1996; Camisón et al., 2000; CIC, 2011 \\
\hline OTHER COMPANIES (ALLIES/COLLABORATORS) \\
Brooking, 1996; Roos et al., 1997; Euroforum, 1998; Camisón et al., 2000; Flostrand, 2006; CIC, 2011 \\
\hline PUBLIC BODIES AND INSTITUTIONS \\
Bontis, 1996; Euroforum, 1998; Camisón et al., 2000; CIC, 2011 \\
\hline CORPORATE REPUTATION AND IMAGE \\
Brooking, 1996; Sveiby, 1997; Euroforum, 1998; CIC, 2011; Gogan \& Dreguici, 2013 \\
\hline
\end{tabular}

Table 3. Elements of relational capital

According to the above, the following hypothesis is established:

H2: There is a positive relationship between each of the elements of relational capital and the internationalization of the university spin-offs.

Relationships with customers stand out for being one of the most commonly studied, thus highlighting the importance that they have for the company, as well as the value of the knowledge and the information that the organization incorporates through them. Relationships with suppliers, competitors, allies or collaborators and public bodies and institutions have been studied in lesser depth. Corporate reputation and image require special mention, as there is a greater discrepancy between those that consider them part of relational capital and those that do not, with the latter understanding that they do not have a very direct or significant influence on good business performance. While it is true that some authors, such as Brooking (1996) and Sveiby (1997), as well as the Intelect (Euroforum, 1998) and Intellectus (CIC, 2011) Models include them on the level of elements of relational capital, others only include them as a measurement indicator of an element of this capital, such as Kaplan and Norton (1992) and Edvinsson (1997), who incorporate them in their customer perspective (CIC, 2011). For this study, reputation is considered to be another element, since companies must focus their attention on it when it comes to selecting the partners with which to establish ties within a certain network, and as a result, to obtain a better positioning in it. The present research will therefore pay attention to all the elements, which 
does not imply that some have a greater or lesser influence than others in the internationalization process. The following sub-hypotheses are thus proposed:

$\mathrm{H}_{2}$ : Relationships with customers, both domestic and international, bave a positive influence on the internationalization process of the university spin-offs.

H2: Relationships with suppliers, both domestic and international, bave a positive influence on the internationalization process of the university spin-offs.

H23: Relationships with competing companies, both domestic and international, have a positive influence on the internationalization process of university spin-offs.

H24: Relationships with other companies (allies/collaborators), both domestic and international, bave a positive influence on the internationalization process of the university spin-offs.

H25: Relationships with public bodies and institutions have a positive influence on the internationalization process of university spin-offs.

H26: The better the reputation and image creation, the more successful the internationalization process is of university spinoffs.

The networks make it possible to delve deeper in the study of how these relationships are configured. According to various studies, networking mitigates the risks of entering into foreign markets (Musteen, Francis \& Datta, 2010), is useful in terms of finding potential partners in other countries, helps identify new business opportunities (Fernhaber \& Li, 2013; Child \& Hsieh, 2014) and reduces investment costs and integration times (Lin \& Chaney, 2007), thus contributing to faster internationalization (Kontinen \& Ojala, 2011; Child \& Hsieh, 2014), by offering the necessary knowledge about new market opportunities (Batas \& Liu, 2013). The following hypothesis is thus offered:

H3: University spin-offs that have strong, reliable networks of relationships, both in the domestic market and abroad, experience greater success in their internationalization process.

It is considered important to investigate the configuration and characterization of the networks. In this way, depending on the commitment made by the company, it may form part of open networks (weakly linked, with the exchange of information among numerous actors) or closed networks (with strong ties, focused on the social exchange, and on trust) (Hilmersson \& Jansson, 2012). The existence of strong ties provides greater benefits for the organization, facilitating the transfer of more detailed information and tacit knowledge, increasing the level of trust and support among the actors who form part of the relationship (Lechner, Frankenberger \& Floyd, 2010).

To contrast the influence that the development of strong ties and the degree of commitment made have on the success of the internationalization process, the following hypotheses are proposed:

H3 1 : The more strong ties that are developed with other agents on the network, the more information the spin-off obtains about foreign markets, and as a result, it experiences greater success in its internationalization process.

$\mathrm{H}_{3}$ : The greater the commitment made by the spin-off in its network of relationships, the greater success will be in its internationalization process.

Along these same lines, it is necessary to analyze whether the time dedicated by the spin-off to the different relationships and the resources that are committed have an influence on its internationalization process, since both concepts (time and resources) have a bearing on the strength or weakness of the links established by the company with the other agents on the network, as described by Granovetter (1973), which leads to the following hypothesis: 
$\mathrm{H}_{3}$ : The more time dedicated and the more resources committed by the company to establishing, developing or maintaining relationships with the different elements that make up the relational capital, the greater will be the success in its internationalization process.

With regard to the type of relationship developed between the company and the other agents of the network, a distinction can be made between formal or professional networks (with customers, suppliers, competitors, allies/collaborators and public institutions) that are extremely relevant in the process of creating knowledge and technological innovation that the spin-offs engage in (McFadyen et al., 2009); and informal or social networks (with friends and family) that are crucial to the success of the creation and development of this type of companies, permitting access to the necessary information and resources, which are supplied by the different agents in the organization's environment (Walter et al., 2006; Huang et al., 2012). Therefore, both types provide the company with relevant and necessary information for the performance of its activity, and thus it is appropriate to analyze how each network has an influence on the internationalization process, as suggested below:

$\mathrm{H}_{4}$ : The more time dedicated and more resources committed by the company to establishing, developing or maintaining formal or professional relationships with the agents of the network, the greater will be the success in its internationalization process.

H35: The more time dedicated and more resources committed by the company to establishing, developing or maintaining informal or social relationships with the agents of the network, the greater will be the success in its internationalization process.

Focusing on the way in which the company establishes itself in a foreign market, it may establish relationships directly or dyadically (a direct relationship between the seller and the buyer, exercising greater control over its product and obtaining greater access to information, which implies greater risks and costs) or indirectly or triadically (a relationship with a third party that acts as an intermediary between the seller and the buyer, resulting in the isolation of the seller from the foreign market, and thus it obtains less knowledge) (Sandberg, 2013). Consequently, it would be interesting to formulate the following hypothesis:

H3 ${ }_{6}$ : The development of dyadic or direct relationships has a greater influence on the business internationalization process than the development of triadic or indirect relationships.

\section{The RC-N-I model}

Following the conclusions drawn from the study of the available literature, the following model has been designed, referred to as the RC-N-I Model (Figure 1), which enables us to analyze the framework of influence of the relational capital in the internationalization of the university spin-offs.

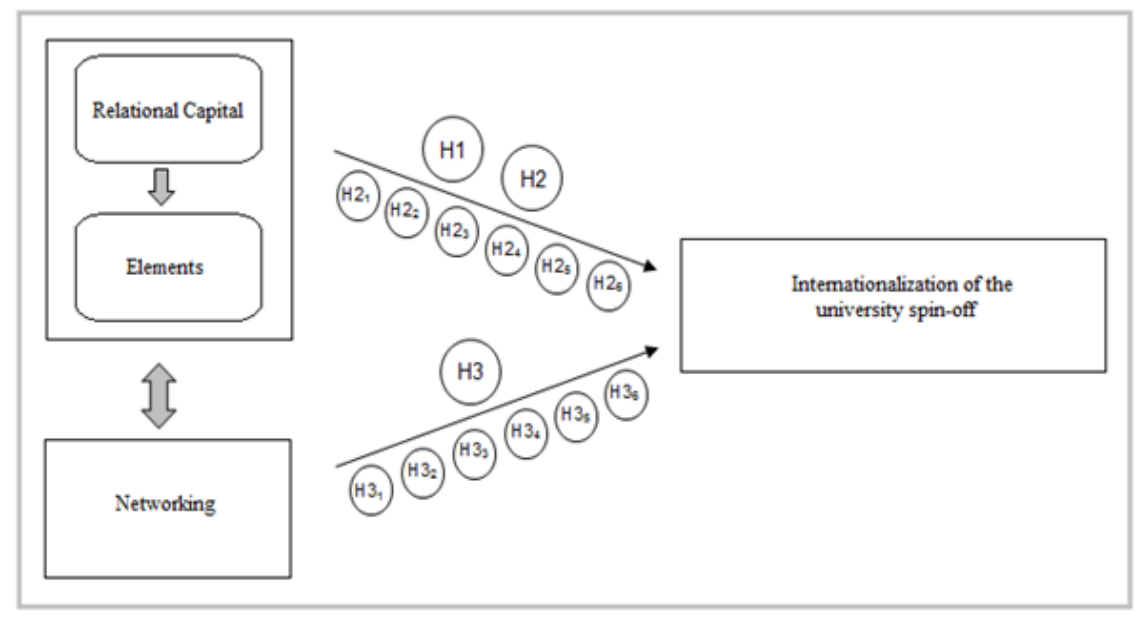

Figure 1. RC-N-I Model 
The model consists of three components, six elements and the different variables and indicators that measure each of these elements, as shown in Table 4 below.

\begin{tabular}{|l|l|}
\hline Components & Elements \\
\hline Relational Capital & Relationships with customers \\
Networking & Relationships with suppliers \\
& Relationships with the competition \\
Internationalization & Relationships with other companies \\
& Relationships with public bodies and institutions \\
& Corporate reputation and image \\
\hline
\end{tabular}

Table 4. Components and elements of the RC-N-I Model

With regard to the different elements of the model, customer relations pertain to those who demand the company's products and potential customers, through which valuable market information can be obtained. Relationships with suppliers refers to those relations the company engages in with those who provide the necessary resources for it to perform its activity. Maintaining good relations with suppliers is an important factor, since it can provide benefits for the organization, such as being able to facilitate access to the necessary resources at a lower cost or better payment conditions. Relationships with the competition, in turn, refers to those relationships between the company and its competitors, regardless of whether they are in the same sector. In terms of allies, collaborative relationships with other organizations are analyzed. In addition to this are relationships with public bodies or institutions, with emphasis on the role they play in the internationalization of the organization, by supplying valuable information and possible economic aid. Finally, reputation and image refer to the perception that other companies, institutions and society in general have of the company.

Tables 5, 6, 7, 8, 9 and 10 below show the variables and indicators related to each of the elements in the model. The selected indicators are those that, a priori, have been stressed and highlighted by the different management and measurement models of intellectual capital.

\begin{tabular}{|l|l|}
\hline Variables & Indicators \\
\hline Relevant customers portfolio & $\begin{array}{l}\text { Relevant extensive portfolio of customers } \\
\text { Relevant foreign customers/total customers } \\
\text { International sales/total sales }\end{array}$ \\
\hline Customer satisfaction & $\begin{array}{l}\text { Satisfied foreign customers/total customers } \\
\text { Perceived level of satisfaction }\end{array}$ \\
\hline Customer loyalty & $\begin{array}{l}\text { Loyal foreign customers/total customers } \\
\text { Repeat purchase index } \\
\text { Level of loyalty }\end{array}$ \\
\hline $\begin{array}{l}\text { Quality of the relationships with } \\
\text { customers }\end{array}$ & $\begin{array}{l}\text { Company satisfaction in its relationships with customers } \\
\text { Company-customer feedback }\end{array}$ \\
\hline
\end{tabular}

Table 5. Variables and indicators of relationships with customers

\begin{tabular}{|l|l|}
\hline Variables & Indicators \\
\hline Supplier base & $\begin{array}{l}\text { Small number of suppliers } \\
\text { Percent of suppliers that provide relevant market information } \\
\text { Foreign suppliers/total suppliers }\end{array}$ \\
\hline $\begin{array}{l}\text { Results of the relationship with } \\
\text { suppliers }\end{array}$ & $\begin{array}{l}\text { Cost savings per supplier } \\
\text { International purchases/total purchases }\end{array}$ \\
\hline Response capacity & $\begin{array}{l}\text { Degree of innovativeness of the supplier } \\
\text { Efficiency in order management }\end{array}$ \\
\hline $\begin{array}{l}\text { Quality of the relationship with } \\
\text { suppliers }\end{array}$ & $\begin{array}{l}\text { Company-supplier feedback } \\
\text { Degree of satisfaction by the organization with its relationship with } \\
\text { suppliers }\end{array}$ \\
\hline
\end{tabular}

Table 6. Variables and indicators of relationships with suppliers 


\begin{tabular}{|l|l|}
\hline Variables & Indicators \\
\hline Competitor base & Number of domestic competitors \\
& $\begin{array}{l}\text { Importance of the competition } \\
\text { No. of foreign competitors/total no. of competitors } \\
\text { Existing agreements with foreign companies }\end{array}$ \\
\hline $\begin{array}{l}\text { Quality of the relationship with } \\
\text { competitors }\end{array}$ & $\begin{array}{l}\text { Characteristics of the existing relationship } \\
\text { Information exchange }\end{array}$ \\
\hline
\end{tabular}

Table 7. Variables and indicators of relationships with the competition

\begin{tabular}{|l|l|}
\hline Variables & Indicators \\
\hline Allies base & $\begin{array}{l}\text { Collaboration agreements/alliances with domestic companies } \\
\text { Collaboration agreements/alliances with foreign companies } \\
\text { Types of alliances (commercial, research, etc.) }\end{array}$ \\
\hline Quality of relationships with allies & $\begin{array}{l}\text { Successful alliances with foreign companies/total alliances } \\
\text { Company-ally feedback } \\
\text { Company satisfaction with its relationship with its allies }\end{array}$ \\
\hline $\begin{array}{l}\text { Results of the relationship with } \\
\text { allies }\end{array}$ & $\begin{array}{l}\text { Benefits obtained } \\
\text { Increase in international customers }\end{array}$ \\
\hline
\end{tabular}

Table 8. Variables and indicators of relationships with other companies

\begin{tabular}{|l|l|}
\hline Variables & Indicators \\
\hline $\begin{array}{l}\text { Agreements/collaboration with } \\
\text { public institutions }\end{array}$ & $\begin{array}{l}\text { No. of collaboration agreements } \\
\text { International presence of public institutions }\end{array}$ \\
\hline Influence on internationalization & $\begin{array}{l}\text { Aid received } \\
\text { Advisement }\end{array}$ \\
\hline
\end{tabular}

Table 9. Variables and indicators of the relationships with public bodies and institutions

\begin{tabular}{|l|l|}
\hline Variables & Indicators \\
\hline Brand recognition & $\begin{array}{l}\text { Percentage of the market that knows the brand } \\
\text { Influence of the brand on the success of the internationalization } \\
\text { Knowledge about the company abroad }\end{array}$ \\
\hline Perceived reputation & $\begin{array}{l}\text { Perceived reputation by customers/suppliers } \\
\text { Perceived reputation by allies/collaborators } \\
\text { Perceived reputation by competitors/other agents }\end{array}$ \\
\hline Business ethics & $\begin{array}{l}\text { Existence and compliance with codes of conduct } \\
\text { Compliance with international regulations (environmental, quality, } \\
\text { etc.) }\end{array}$ \\
\hline Social and environmental action & $\begin{array}{l}\text { Activities aimed at improving the welfare of society } \\
\text { Activities aimed at environmental protection }\end{array}$ \\
\hline Influence on internationalization & $\begin{array}{l}\text { Importance of the brand in the internationalization process } \\
\text { Importance of the image in the internationalization process } \\
\text { Importance of the reputation in the internationalization process }\end{array}$ \\
\hline
\end{tabular}

Table 10. Variables and indicators of the corporate reputation and image

Each of the elements mentioned above (except for reputation and image) are, in turn, analyzed from the perspective of the networks by incorporating the following variables and indicators set out in Table 11. 


\begin{tabular}{|l|l|}
\hline Variables & Indicators \\
\hline Establishment of ties & $\begin{array}{l}\text { Degree of knowledge of the element (customers, suppliers, } \\
\text { competition, other companies and institutions) } \\
\text { Intensity of the relationship } \\
\text { Level of mutual trust }\end{array}$ \\
\hline Commitment made & $\begin{array}{l}\text { Degree of commitment made } \\
\text { Degree of shared knowledge and information } \\
\text { Coordination of activities } \\
\text { Shared beliefs and visions }\end{array}$ \\
\hline Shared time and resources & $\begin{array}{l}\text { Amount of time dedicated to establishing, developing and } \\
\text { consolidating the relationship } \\
\text { Duration of the relationship } \\
\text { Frequency of interaction } \\
\text { Amount of shared resources } \\
\text { Number of shared resources }\end{array}$ \\
\hline Type of relationship & $\begin{array}{l}\text { Informal or formal } \\
\text { Direct or with intermediaries }\end{array}$ \\
\hline
\end{tabular}

Table 11. Variables and indicators from the perspective of networks

\section{Conclusions}

The present article sheds light on the importance that relational capital and networking have in the internationalization process of university spin-offs.

Form the theoretical analysis, it can be concluded that the performance of international activities by a university spin-off depends on its skill in creating and maintaining relationships with different agents in its environment, through which it obtains outside resources and information that are very valuable from a strategic perspective, and specifically that information relative to the situation of the environment, the market and the competition, which noticeably reduces the possibilities of business failure.

Companies must be made aware of the importance of these relationships and the benefits that they provide. They must also have the tools for their proper strategic management, which is even more relevant in the case of university spin-offs, due to the high level of complexity of the innovative process they carry out.

In addition to engaging in internal $\mathrm{R} \& \mathrm{D}$ activities, this type of companies have the need to acquire knowledge for the optimal development of their activity process. It is here where the relational capital and networking come into play, providing them with greater access to the necessary information and knowledge.

All of the above reveals the existence of a vast body of literature on these concepts (relational capital, networking, internationalizations and university spin-offs), but the joint analysis of all of them represents an interesting challenge, which the present research has attempted to address. Its main contribution has been to give companies a tool for strategic analysis that enables them to exploit their relational capital to obtain competitive advantages or generate value, analyzing in depth the effect that the different elements that make up said capital have on the internationalization of university spin-offs and the ties among them.

It should be emphasized that this study represents the first step towards more in-depth research in the future on the phenomenon of internationalization, and more specifically, on the behavior of the relational capital agents that form part of the networks of internationalization in the technology sector, to which the university spin-offs belong.

Finally, with regard to future lines of research, a hybrid methodology (qualitative and quantitative analysis) is proposed, in which a case study would make it possible to validate ad reinforce the proposed model, then proceeding to the application of the same in the area of Spanish spin-offs. This would generate a series of useful strategic guidelines for decision-making in the area of the internationalization of the companies concerned. 


\section{Declaration of Conflicting Interests}

The author declared no potential conflicts of interest with respect to the research, authorship, and/or publication of this article.

\section{Funding}

The authors received no financial support for the research, authorship, and/or publication of this article.

\section{References}

Alarcón, M.A. (2013). Sharing strategical resources in critical junctures for the technology-based firms. Quantitativa Revista de Economía, 3(1), 66-85.

Audretsch, D.B. (2013). The entrepreneurial society \& the role of the University. ECONOMLA MARCHE Journal of Applied Economics, 32(2), 6-16.

Barroso-González, M., Jiménez-García, M., \& Pérez-González, M. (2014). Incidencia de diferentes sistemas territoriales de innovación en la creación de Empresas de Base Tecnológica (EBTs). Una aplicación al caso andaluz. Revista de Globalización, Competitividady Gobernabilidad, 8(3), 62-82.

Batas, S., \& Liu, L. (2013). The Internationalization Process of Born Global High Technology SMEs: The Moderating Role of Business and Social Networks, International Innovation Conference (SIIC), Suzhou-Silicon Valley-Beijing. https://doi.org/10.1109/SIIC.2013.6624161

Beldad, A.T. (2013). La aplicación social de la investigación: Hacia una Universidad Emprendedora. Encuentros multidisciplinares, 15(44), 36-46.

Bontis, N. (1996). There is a price on your head: managing intellectual capital strategically. Business Quaterly, verano, 41-47.

Bontis, N. (2001). National intellectual capital index: Intellectual capital development in the Arab Region. Ontario: Institute for Intellectual Capital Research.

Brooking, A. (1996). Intellectual capital. Core asset for the triad millenium enterprise. Londres: International Thomson Business Press.

Camisón, C., Palacios, D., \& Devece, C. (2000). Un nuevo modelo para la medición del capital intelectual: El modelo Nova. X Congreso ACEDE, Septiembre, Universidad Oviedo.

Carayannis, E., Rogers, E., Kurihara, K., \& Allbritton, M. (1998). High technology spin-offs from government R\&D laboratories and research institutes. Technovation, 18, 1-10. https://doi.org/10.1016/S0166-4972(97)00101-6

Chang, Y. (2003). Benefits of co-operation on innovative performance: evidence from integrated circuits and biotechnology firms in the UK and Taiwan. R\&DD Management, 33, 425-437. https://doi.org/10.1111/14679310.00308

Chen, Y. (2008). The Positive Effect of Green Intellectual Capital on Competitive Advantages of Firms. Journal of Business Ethics, 77, 271-286. https://doi.org/10.1007/s10551-006-9349-1

Child, J., \& Hsieh, L.H.Y. (2014). Decision Mode, Information and Network Attachment in the Internationalization of SMEs: A Configurational and Contingency Analysis. Journal of World Business, 49(4), 598-610. https://doi.org/10.1016/j.jwb.2013.12.012

CIC (2003). Modelo Intellectus: Medición y Gestión del Capital Intelectual. Documento No 5. Universidad Autónoma de Madrid (Centro de Investigación sobre la Sociedad del Conocimiento, CIC), Madrid.

CIC (2011). Modelo Intellectus: Medición y Gestión del Capital Intelectual. Documento No 9/10. Universidad Autónoma de Madrid (Centro de Investigación sobre la Sociedad del Conocimiento, CIC), Madrid.

De Leaniz, P. M. G., \& Del Bosque, I. R. (2013). Intellectual capital and relational capital: The role of sustainability in developing corporate reputation. Intangible Capital, 9(1), 262-280. 
Díaz-Díaz, N.I., \& De Saá-Pérez, P. (2007). El Papel de los Recursos Humanos de I+D en la Absorción del Conocimiento Adquirido mediante Alianzas. Congreso Nacional de ACEDE, Sevilla.

Edvinsson, L. (1997). Intellectual Capital shapes the future enterprise. Scandinavian Insurance Quarterly, 1.

Euroforum (1998). Medición del capital intelectual: Modelo Intelect, I.U. Madrid: Euroforum Escorial.

Federico, J., Kantis, H., Rialp, A., \& Rialp, J. (2009). Does entrepreneurs' human and relational capital affect early internationalization? A cross-regional comparison. European journal of International Management, 3(2), 199-215. https://doi.org/10.1504/EJIM.2009.024322

Fernhaber, S.A., \& Li, D. (2013). International exposure through network relationships: Implications for new venture internationalization. Journal of Business Venturing, 28, 316-334.

https://doi.org/10.1016/j.jbusvent.2012.05.002

Fletcher, R. (2008). The internationalization from a network perspective: A longitudinal study. Industrial Marketing Management, 37(8), 953-964. https://doi.org/10.1016/j.indmarman.2007.09.008

Flostrand, P. (2006). The Sell Side Observations on Intellectual Capital Indicators. Journal of Intellectual Capital, 7(4), 457-473. https://doi.org/10.1108/14691930610709112

Fonfría, A. (2010). Innovación tecnológica e internacionalización: Un análisis causal. DyO, 42, 30-50.

Gogan, L.M., \& Dreguici, A. (2013). A model to evaluate the intellectual capital. Procedia Technology, 9, 867-875. https://doi.org/10.1016/j.protcy.2013.12.096

Granovetter, M. (1973). The strength of weak ties. The American Journal of Sociology, 78(6), 1360-1380. https://doi.org/10.1086/225469

Guercini, S., \& Runfola, A. (2010). Business networks and retail internationalization: A case analysis in the fashion industry. Industrial Marketing Management, 39(6), 908-916.

https://doi.org/10.1016/j.indmarman.2010.06.010

Hilmersson, M., \& Jansson, H. (2012). Internationalization of Small and Medium-sized Enterprises from the Baltic States to Mature Markets in the EU. Journal of International Marketing, 20(4), 96-110. https://doi.org/10.1509/jim.12.0052

Hollensen, S. (2014). Global Marketing: A decision-oriented approach. Harlow Pearson Education.

Hormiga, E., Batista-Canino, R.M., \& Sánchez-Medina, A. (2011). The role of intellectual capital in the success of new ventures. International Entrepreneurship Management Journal, 7, 71-92. https://doi.org/10.1007/s11365-010$0139-\mathrm{y}$

Huang, H.C., Lai, M.C., \& Lo, K.W. (2012). Do founders' own resources matter? The influence of business networks on start-up innovation and performance. Technovation, 32(5), 316-327.

https://doi.org/10.1016/j.technovation.2011.12.004

Iglesias, P., Maldonado, C., \& Velasco, A. (2012). Caracterización de las spin-off universitarias como mecanismo de transferencia de tecnología a través de un análisis clúster. Revista Europea de Dirección y Economía de la Empresa, 21(3), 240-254. https://doi.org/10.1016/j.redee.2012.05.004

Iglesias, P., Maldonado, C., \& Velasco, A. (2014). Comparación de la actividad de I+ D+ i de Spin-Off universitarias y otras organizaciones empresariales. Economía industrial, 392, 155-168.

Kaplan, R., \& Norton, D. (1992). The Balanced Scorecard-measures that drive performance. Harvard Business Review, January-February, 71-79.

Kontinen, T., \& Ojala, A. (2011). Network ties in the international opportunity recognition of family SMEs. International Business Review, 20(4), 440-453. https://doi.org/10.1016/j.ibusrev.2010.08.002 
Landry, R., Amara, N., \& Rherrad, I. (2006). Why are some university researchers more likely to create spin-offs than others? Evidence from Canadian universities. Research Policy, 35, 1599-1615.

https://doi.org/10.1016/j.respol.2006.09.020

Lechner, C., Frankenberger, K., \& Floyd, S. W. (2010). Task contingencies in the curvilinear relationships between intergroup networks and initiative performance. Academy of Management Journal, 53(4), 865-889. https://doi.org/10.5465/amj.2010.52814620

Lin, K.H., \& Chaney, I. (2007). The influence of domestic interfirm networks on the internationalization process of Taiwanese SMEs. Asia Pacific Business Review, 13(4), 565-583. https://doi.org/10.1080/13602380701345499

Lockett, A., \& Wright, M. (2005). Resources, capabilities, risk capital and the creation of university spin-out companies. Research Policy, 34(7), 1043-1057. https://doi.org/10.1016/j.respol.2005.05.006

McFadyen, M.A., Semadeni, M., \& Canella, A. (2009). Value of Strong Ties to Disconnected Others: Examining Knowledge Creation in Biomedicine. Organization Science, 20(3), 552-564. https://doi.org/10.1287/orsc.1080.0388

McQueen, D.H., \& Wallmark, J.T. (1982). Spin-Off companies from Chalmers University of Technology. Tecbnovation, 1, 305-315. https://doi.org/10.1016/0166-4972(82)90010-4

Musteen, M., Francis, J., \& Datta, D.K. (2010). The influence of international networks on internationalization speed and performance: A Study of Czech SMEs. Journal of World Business, 45(3), 197-205. https://doi.org/10.1016/j.jwb.2009.12.003

Owais, W.O. (2014). Intellectual Capital Management and Reporting in Jordanian Universities. Research Journal of Finance and Accounting, 5(12), 59-69.

Ozdemir, N. (2017). Intellectual Capital Management in the Context of Internationalization. In European Conference on Intellectual. Academic Conferences International Limited.

Ozgen, E., \& Baron, R.A. (2007). Social sources of information in opportunity recognition: effects of mentors, industry networks, and professional forums. Journal of Business Venturing, 22, 174-192.

https://doi.org/10.1016/j.jbusvent.2005.12.001

Pérez, P.M., \& Sánchez, A. (2003). The development of university spin offs: early dynamics of technology transfer and networking. Technovation, 23, 823-831. https://doi.org/10.1016/S0166-4972(02)00034-2

Presutti, M., Boari, C., \& Fratocchi, L. (2016). The evolution of interorganizational social capital with foreign customers: its direct and interactive effects on SMEs' foreign performance. Journal of World Business, 51(5), 760-773. https://doi.org/10.1016/j.jwb.2016.05.004

Rodeiro, D. (2008). La creación de empresas en el Sistema Universitario Español, Servicio de Publicaciones e Intercambio Cientifico, Santiago de Compostela.

Rodenes, M., \& González, D. (2008). La influencia del capital relacional, innovación tecnológica y orientación al Mercado sobre los resultados empresariales en empresas de alta tecnología: Un modelo conceptual. Pensamiento Y Gestión, 25, 113-138.

Roos, G., \& Roos, J. (1997). Measuring your company's intellectual performance. Long Range Planning, 30(3), 413-426. https://doi.org/10.1016/S0024-6301(97)90260-0

Roos, J., Roos, G., Dragonetti, N.C., \& Edvinsson, L. (1997). Intellectual Capital, Navigating the New Business Landscape. London: Macmillan Business.

Saint-Onge, H. (1996). Tacit knowledge the key to the strategic alignment of intellectual capital. Strategy \& Leadership, 24(2), 10-16.

Sandberg, S. (2013). Emerging market entry node pattern and experiential knowledge of small and medium-sized enterprises. International Marketing Review, 30(2), 106-129. https://doi.org/10.1108/02651331311314547

Shane, S. (2004). Academic entrepreneurship: University spin-offs and wealth creation. Northampton, MA: Edward Elgar. https://doi.org/10.4337/9781843769828 
Steinar, B. (2014). International Networking Strategies in Academics Spin-off Companies. Norwegian University of Science and Technology.

Stuart, T. (2000). Interorganizational alliances and the performance of firms: A study of growth and innovation rates in a high-technology industry. Strategic Management Journal, 21, 791-811. https://doi.org/10.1002/10970266(200008)21:8<791::AID-SMJ121>3.0.CO;2-K

Sveiby, K.E. (1997). The new organizational wealth: Managing \& measuring knowledge-based assets. San Francisco: BerrettKoehler Publishers.

Sydler, R., Haefliger, S., \& Pruksa, R. (2014). Measuring intellectual capital with financial figures: Can we predict firm profitability?. European Management Journal, 32(2), 244-259. https://doi.org/10.1016/j.emj.2013.01.008

Treibich, T., Konrad, K., \& Truffer, B. (2013). A dynamic vie won interactions between academic spin-offs and their parent organizations. Technovation, 33, 450-462. https://doi.org/10.1016/j.technovation.2013.06.012

Valente, T. (2014). Innovazione, trasferimento tecnologico e sviluppo: Le imprese spin-off. TECHNE, 7(1), $21-26$.

Valmaseda, O., \& Hernández, N. (2012). Fuentes de conocimiento en los procesos de innovación empresarial: las Spin-Off universitarias. Arbor, 188(753), 211-228. https://doi.org/10.3989/arbor.2012.753n1013

Vargas, C. (2011). Las Spin-Offs Académicas y su possible configuración como empresas de economía social, de la ley orgánica de universidades a la ley de la ciencia, la tecnología y la innovación, XXX Seminario Nacional y XIV Seminario Internacional de Investigación en materia de sociedades de participación, Murcia.

Vatamanescu, E.M., Zbuchea, A., Pînzaru, F., \& Andrei, A.G. (2016). The Impact of Relational Capital on SMES Internationalization. Leveraging Versus Offline Business Networking. In European Conference on Knowledge Management (pp. 926). Academic Conferences International Limited.

Villanueva-Felez, A., Fernández-Zubieta, A., \& Palomares-Montero, D. (2014). Propiedades relacionales de las redes de colaboración y generación de conocimiento científico: ¿Una cuestión de tamaño o equilibrio?. Revista Española de Documentación Cientifica, 37(4). https://doi.org/10.3989/arbor.2012.753n1013

Villasalero, M. (2014). University knowledge, open innovation and technological capital in Spanish science parks: Research revealing or technology selling?. Journal of Intellectual Capital, 15(4), 479-496. https://doi.org/10.1108/JIC-07-2014-0083

Visintin, F., \& Pittino, D. (2014). Founding team composition and early performance of university-Based spin off companies. Technovation, 34, 31-43. https://doi.org/10.1016/j.technovation.2013.09.004

Walter, A., Auer, M., \& Ritter, T. (2006). The impact of network capabilities and entreprenurial orientation on university spin-off performance. Journal of Business Venturing, 21, 541-657. https://doi.org/10.1016/j.jbusvent.2005.02.005

Zahra, S., Van de Velde, E., \& Larraneta, B. (2007). Knowledge conversion capability and the growth of corporate and university spin offs. Industrial and Corporate Change, 16(4), 569-608.

https://doi.org/10.1093/icc/dtm018

Intangible Capital, 2019 (www.intangiblecapital.org)

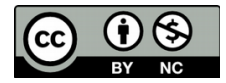

Article's contents are provided on an Attribution-Non Commercial 4.0 Creative commons International License. Readers are allowed to copy, distribute and communicate article's contents, provided the author's and Intangible Capital's names are included. It must not be used for commercial purposes. To see the complete license contents, please visit https://creativecommons.org/licenses/by-nc/4.0/. 